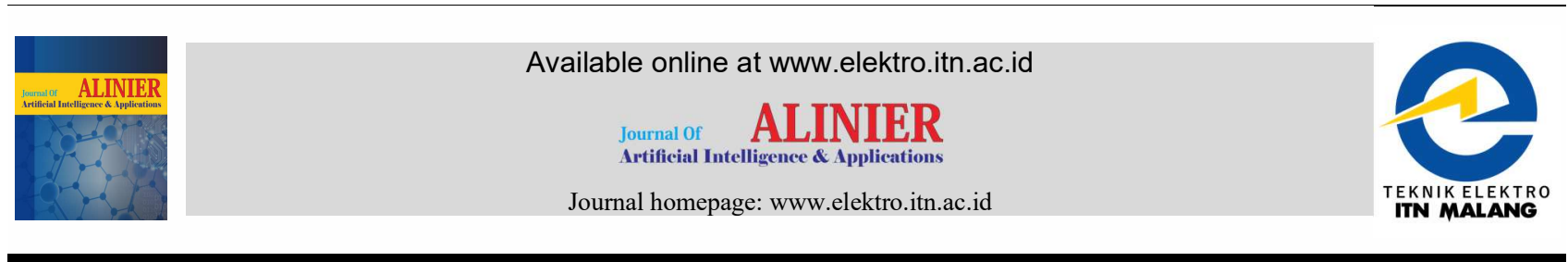

\title{
Modifikasi Firefly Algorithm Untuk Partial Shading pada Photovoltaic
}

\author{
Budiman, Machrus Ali* \\ Universitas Darul ulum,Jalan Gus Dur 29A, Jombang 61411, Indonesia \\ *machrus4@gmail.com
}

Kata Kunci :

$F A$

$M F A$

Optimization

PID

Photovoltaic

\begin{abstract}
ABSTRAK
Shadows of buildings or trees can partially cover the PV resulting in differences in solar radiation reception. Partial shading occurs when the PV module receives different solar radiation due to shadows of buildings or trees or clouds. This condition causes the output power of the PV array to decrease. Based on the PV curve, partial shading has a direct effect, so that a decrease in voltage or current causes a decrease in the output power of the PV. Because this requires a good control device. In this study, the method was compared without control (Uncontrolled), conventional PID (PID), PID tuned by Firefly Algorithm (PID- FA), and PID tuned by Modified Firefly Algorithm (PID-MFA). From the simulation results, it is found that the best voltage is obtained from the PID-MFA controller, the best voltage obtained from the PID-MFA controller is $1.2755 \mathrm{pu}$, the best current on the PID-MFA is 4,313; 3.67; 2,551 pu, and the maximum power is 3,253 pu. Thus it can be concluded that the best controller is PID-MFA. This research can later be used as a reference and other controllers are used to obtain an optimal controller.
\end{abstract}

\section{Pendahuluan}

Berkurangnya ketersediaan energi konvensional dan peningkatan gas rumah kaca dan polusi berdampak usaha meningkatkan kontribusi energi terbarukan. Saat ini sumber energi alternatif yang paling banyak digunakan adalah sumber energi matahari. Sehingga sistem konversi energi matahari (photovoltaic/solar cell) menjadi energi listrik dengan percepatan penggunaan yang cepat di berbagai negara. Sistem Photovoltaic (PV) mempunyai banyak kelebihan, diantaranya biaya perawatannya yang rendah dan tidak mencemari lingkungan. Photovoltaic (PV) array yang menerima radiasi sinar matahari mempunyai karakteristik penyesuaian arus dan tegangan yang berubah-ubah sesuai dengan radiasi yang diterima. Dengan Maximum Power point (MPP) PV dapat menghasilkan daya output yang maksimum. Pengoptimalan kinerja sistem PV digunakan Maximum Power Point Tracking (MPPT). Digunakan untuk mendeteksi dan mengatur daya maksimum yang dapat dihasilkan oleh system PV dalam kondisi perubahan 
suhu dan radiasi matahari.

Algoritma pelacakan titik daya maksimum berfungsi untuk menjaga tegangan keluaran dari panel PV. Konverter dc-dc digunakan karena tegangan keluaran dari panel surya berupa tegangan DC. Umumnya digunakan konverter boost sebagai perangkat pelacakan titik daya maksimum. Konverter boost ini hanya bekerja jika tagangan masukan lebih kecil dari tegangan luaran yang dinginkan. Jika tegangan dari panel surya lebih besar dari tegangan yang dinginkan maka konverter boost tidak akan bekerja akibatnya daya maksimum dari panel surya juga tidak tercapai.

Telah banyak metode algoritma Artificial Intelligent (AI) yang digunakan untuk penerapan sistem tenaga listrik, diantaranya adalah Firefly Algorithm (FA). FA sering digunakan karena mampu memperoleh konvergensi lebih capat dan proses komputasi yang sangat sederhana diantaranya telah digunakan pada kontrol kendaran[1][2][3][4], kontrol mikro hidro[5], kontrol turbin angin[6], kontrol mesin diesel[6], kontrol kecepatan motor[7][8], kontrol level air[9][10], dan kontrol traking photovoltaic[11]. MFA merupakan algoritma yang memodifikasi Metode Firefly Alghorithm yang mampu mengoptimasikan pada system photovoltaic[12][13]. Sehingga pada makalah ini akan didesain MPPT pada sistem photovoltaic pada konsisi partial shading dengan menggunakan algoritma MFA.

\section{Photovoltaic}

\section{A. Pemodelan}

Pada makalah ini, photovoltaic / solar cell digunakan sebagai sumber utama dari sistem. photovoltaic dimodelkan sebagai sebuah rangkaian ekuivalen yang ditunjukkan pada Gambar 1. Rsh dan Rs adalah resistansi intrinsic yang tersusun secara paralel dan seri. Nilai Rsh adalah sangat besar sedangkan Rs sangat kecil. Hal ini mengakibatkan dua variabel tersebut dapat secara mudah diabaikan dalam proses analisis. Solar cell yang tersusun menjadi unit yang lebih besar disebut modul-modul photovoltaic. Kemudian, modul-modul photovoltaic dihubungkan secara seri dan paralel untuk membentuk photovoltaic arrays.

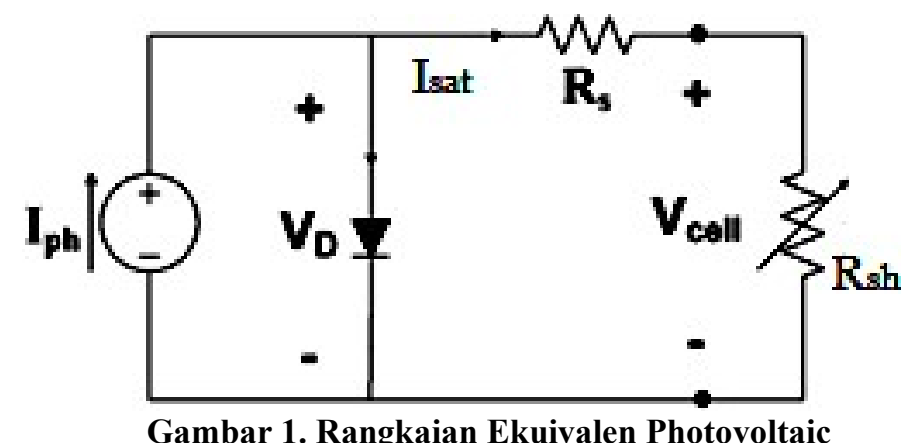

Model matematis dari Photovoltaic arrays dapat direpresentasikan dengan persamaan seperti berikut:

$$
I_{P V}=n_{p} I_{p h}-n_{p} I_{\text {sat }}\left[\exp \left(\frac{q}{K A T} \frac{V_{P V}}{n_{s}}\right)-1\right]
$$


Dengan IPV adalah arus output dari PV arrays (dalam Ampere), VPV adalah tegangan output dari PV arrays, ns adalah jumlah modul yang tersusun secara seri, np adalah jumlah modul yang tersusun secara paralel, $\mathrm{q}$ adalah muatan elektron, $\mathrm{K}$ adalah konstanta Boltzmann, A adalah faktor ideal dari p-n junction, $\mathrm{T}$ adalah suhu solar cell (dalam Kelvin), dan Isat adalah arus saturasi negatif.

B. Partial Shading Pada Sistem PV

Sebuah modul PV terdiri dari beberapa sel PV yang terhubung secara seri untuk menghasilkan tegangan yang lebih tinggi dan terhubung secara paralel untuk meningkatkan arus. Beberapa modul PV kemudian dihubungkan secara seri dan paralel untuk membentuk sebuah sistem PV. Berdasarkan kondisi partial shading, kurva daya (P) pada modul PV akan menampilkan beberapa Maximum Power Point (MPP) dikarenakan dioda bypass pada PV. Global Maximum Power Point (GMPP) dapat terjadi baik dalam rentang tegangan rendah atau tinggi tergantung pada jenis pola partial shading. Oleh karena itu, algoritma MPPT konvensional akan sulit diterapkan pada fenomena ini.

Tabel 1. Parameter Modul PV

\begin{tabular}{ll}
\hline Daya Maksimum (Pm) & 130 Watt \\
\hline Tegangan Open Circuit(Vo) & 38.68 Volt \\
\hline $\begin{array}{l}\text { Tegangan Pada } \\
\text { Saat Daya }\end{array}$ & 34,67 Volt \\
Maksimum(Vm) & \\
\hline Arus Short Circuit(Is) & 3.8 Ampere \\
\hline $\begin{array}{l}\text { Arus Pada Saat Daya } \\
\text { Maksimum(Im) }\end{array}$ & 3.77 Ampere \\
\hline
\end{tabular}

\section{Metode Penelitian}

A. PID Controller

Kontrol PID banyak digunakan pada industri khususnya aplikasi kontrol karena strukturnya simple, algoritma kontrol yang konperhensip, dan biayanya murah. PID merupakan controller untuk menentukan kepresisian suatu sistem instrumentasi dengan karakteristik adanya umpan balik / feed back pada sistem tersebut. Komponen PID terdiri dari 3 jenis, yaitu Proportional, Integratif, dan Derivatif. Ketiganya dapat dipakai bersamaan maupun sendiri- sendiri, tergantung dari respon yang kita inginkan terhadap suatu plant. [14]

B. Firefly Algorithm (FA)

Algorithm Firefly (FA) pertama ditemukan oleh Dr.Xin-She Yang di Universitas Cambridge pada tahun 2007[15]. Dalam proses permasalahan optimisasi, kecerahan cahaya kunangkunang adalah sebanding untuk nilai dari fungsi tujuan. Bentuk lain dari kecerahan dapat didefinisikan pada cara yang sama untuk fungsi fitness pada algoritma genetika. Dalam proses permasalahan optimisasi, kecerahan cahaya kunang-kunang adalah sebanding untuk nilai dari fungsi tujuan[7]. Berdasarkan pada ketiga peraturan ini, langkah dasar dari algoritma kunang-kunang dapat diringkas sebagai pseudo code. Data parameter-parameter 
standar FA yang digunakan ditunjukkan pada Tabel 2 berikut:

Tabel 2 Parameter FA

\begin{tabular}{ll}
\hline Parameter & Nilai \\
\hline Beta & 0.5 \\
Alpha & 0.5 \\
Gamma & 0.5 \\
Dimensi & 3 \\
Jumlah Kunang-Kunang & 50 \\
Iterasi maksimum & 50 \\
\hline
\end{tabular}

C. Modified Firefly Alghorithm (MFA)

Paremater-parameter yang perlu diucicobakan adalah dengan mengubah nilai-nilai dari beta, gama dan alpha sekaligus, yaitu:

Dengan memodifikasi nilai beta pada setiap iterasi dengan persamaan pada program betamin $=0.1+(0.8 *(\mathrm{kq} /$ MaxGeneration $))$;

Nilai beta pada setiap iterasi akan berubah (bertambah) mulai dari 0.1 pada iterasi pertama sampai 0.9 pada itarasi terakhir. Pada iterasi pertama diberikan nilai betamin sebesar 0.1 bertujuan untuk memberikan ancang-ancang firefly dalam mencari target. pada iterasi berikutnya nilai betamin bertambah sampai target akhir terlihat jelas. Karena target akhir sudah terlihat jelas maka nilai betamin (kecepatan) diberikan nilai maksimal (0.9).

Dengan memodifikasi nilai alpha pada setiap iterasi dengan persmaan pada program alpha $=0.9-(0.8 *(\mathrm{kq} /$ MaxGeneration $))$;

Nilai alpha pada setiap iterasi akan berubah (berkurang) mulai dari 0.9 pada iterasi pertama sampai 0.1 pada iterasi terakhir. Pada iterasi pertama alpha (fleksibilitas) diberikan nilai maksimum (0.9), pada iterasi berikutnya nilai alpha berkurang sampai terlihat target akhir. Karena target sudah terlihat jelas maka nilai alpha diberikan nilai minimal (0.1). [13]

Nilai gamma $=0$, tidak diperlukan karena bukan merupakan kasus yang sangat kompleks.

D. Desain PV

Desain Simulink PV untuk partial shadding dapat dilihat pada gambar 2:

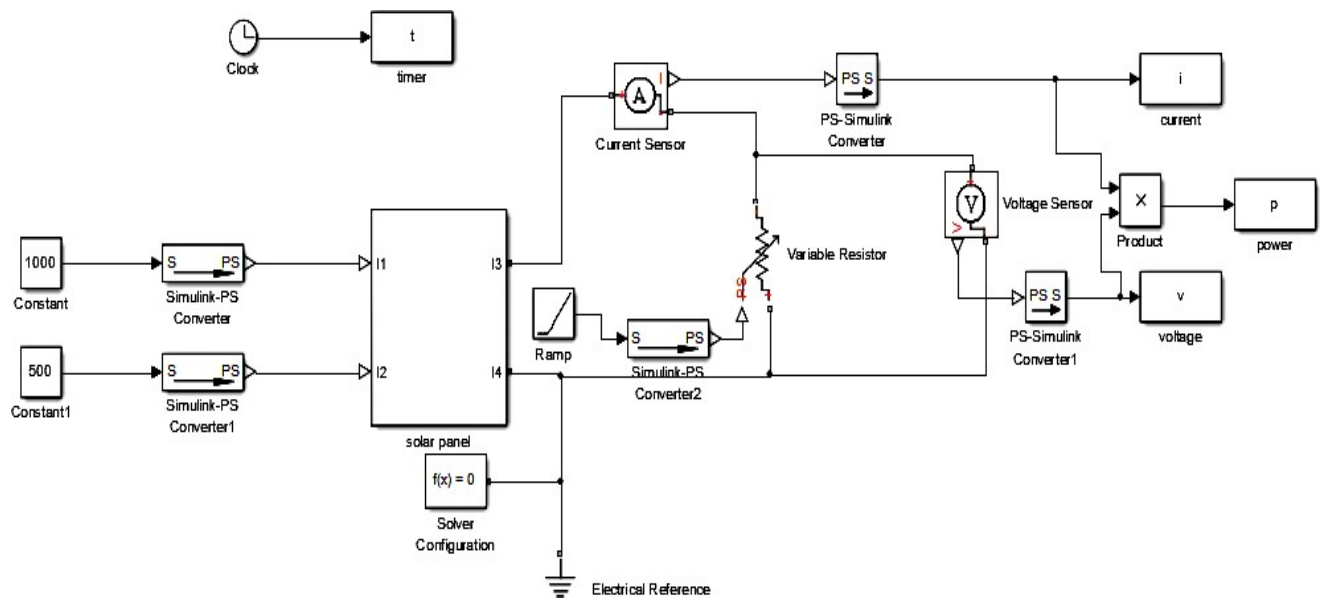

Gambar 2 Simulasi Sistem Photovoltaic 


\section{Analisa dan Pembahasan}

Konstanta hasil simulasi didapatkan konstanta kp, ki, dan kd seperti pada tabel 3.

Tabel 3. Konstanta PID

\begin{tabular}{lllll}
\hline & Unc & PID & PID-FA & PID-MFA \\
\hline $\mathrm{Kp}$ & - & 1 & 29.502 & 45.035 \\
$\mathrm{Ki}$ & - & 1 & 2.031 & 4.441 \\
$\mathrm{Kd}$ & - & 0 & 1.032 & 1.043 \\
\hline
\end{tabular}

Desain tanpa kontrol, PID kontrol, PDI-FA, dan PID-ACO dapat dilihat pada gambar 3.

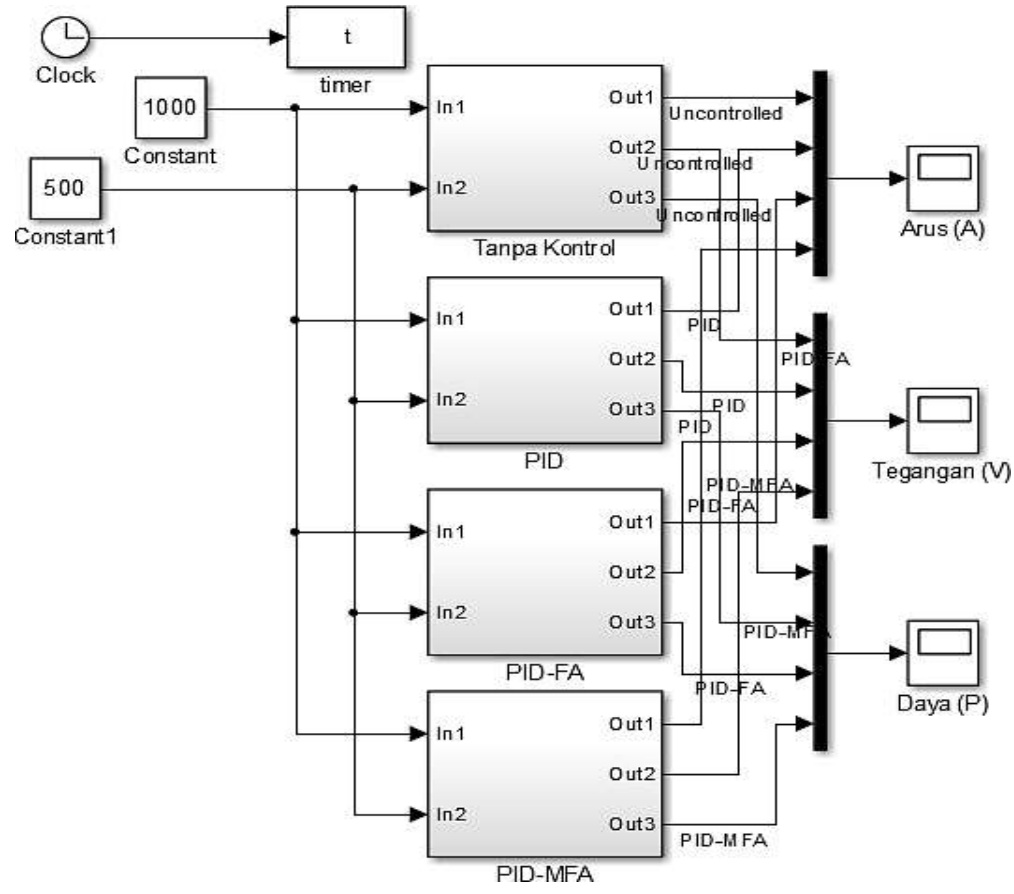

Gambar 3. Desain kontrol partial shading pada PV

Hasil output tegangan (V) pada partial shading dapat dilihat pada gambar 4

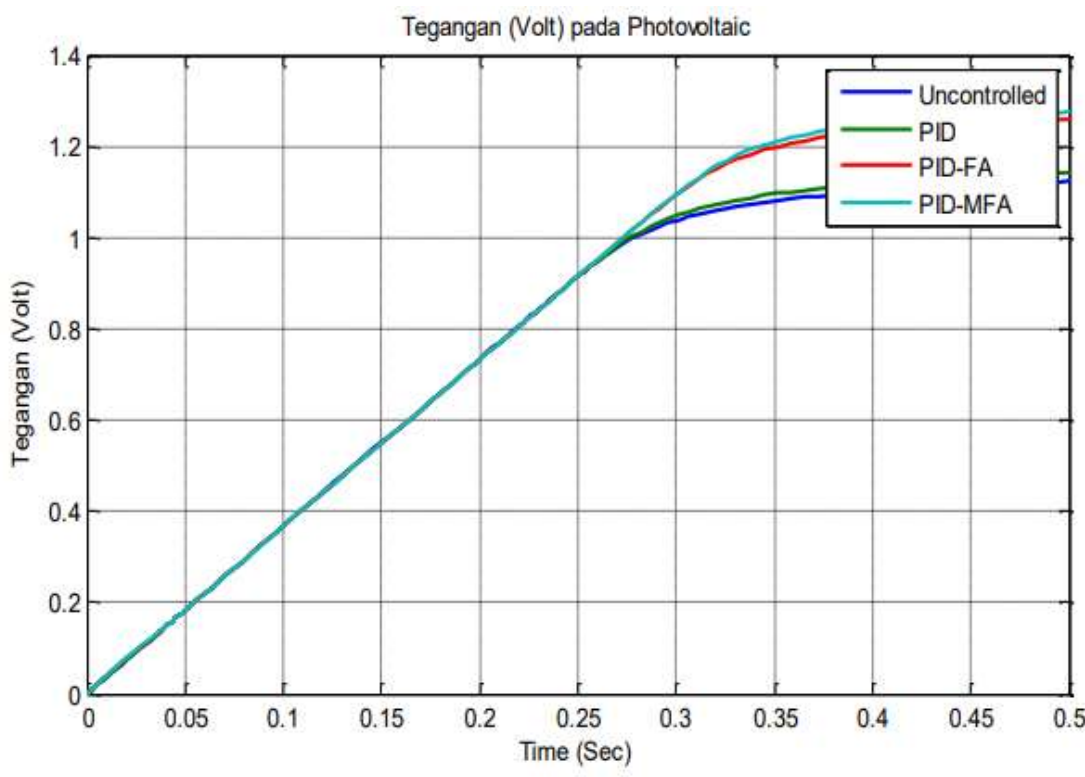

Gambar 4 Output Tegangan Pada Partial Shading Pada PV 
Dari gambar 4 menunjukkan bahwa tegangan maksimum dapat diperoleh pada PV tanpa control sebesar 1.1227 pu, dengan PID konfensional sebesar 1.1442 pu, dengam control PID dengan tuning FA sebesar $1.2596 \mathrm{pu}$, dan dengan tuning MFA sebesar 1.2755 pu. Sehingga dapat diartikan bahwa controller PID-MFA adalah controller terbaik dalam penelitian ini. Hasil output arus (A) pada partial shading dapat dilihat pada gambar 5

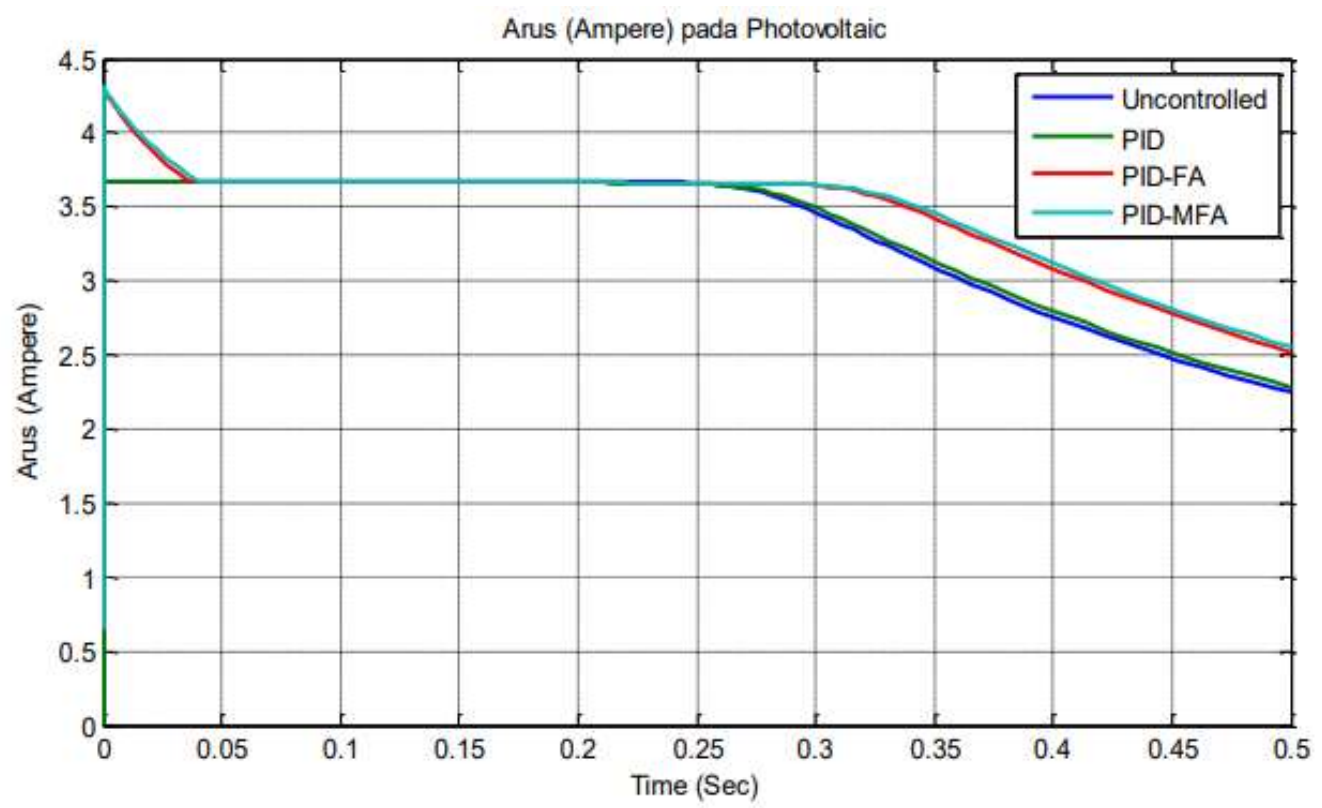

Gambar 5 Output Arus Pada Partial Shading Pada PV

Dari gambar 4 menunjukkan bahwa arus maksimum dapat diperoleh pada PV tanpa control sebesar 3,67 ; 3,67 ; 2,25 pu, dengan PID konfensional sebesar 3,67 ; 3,67 ; 2,27 pu, dengam control PID dengan tuning FA sebesar 4,$251 ; 3.67 ; 2,547 \mathrm{pu}$, dan dengan tuning MFA sebesar 4,$313 ; 3.67 ; 2,551$ pu.

Hasil output daya $(\mathrm{P})$ pada partial shading dapat dilihat pada gambar 6

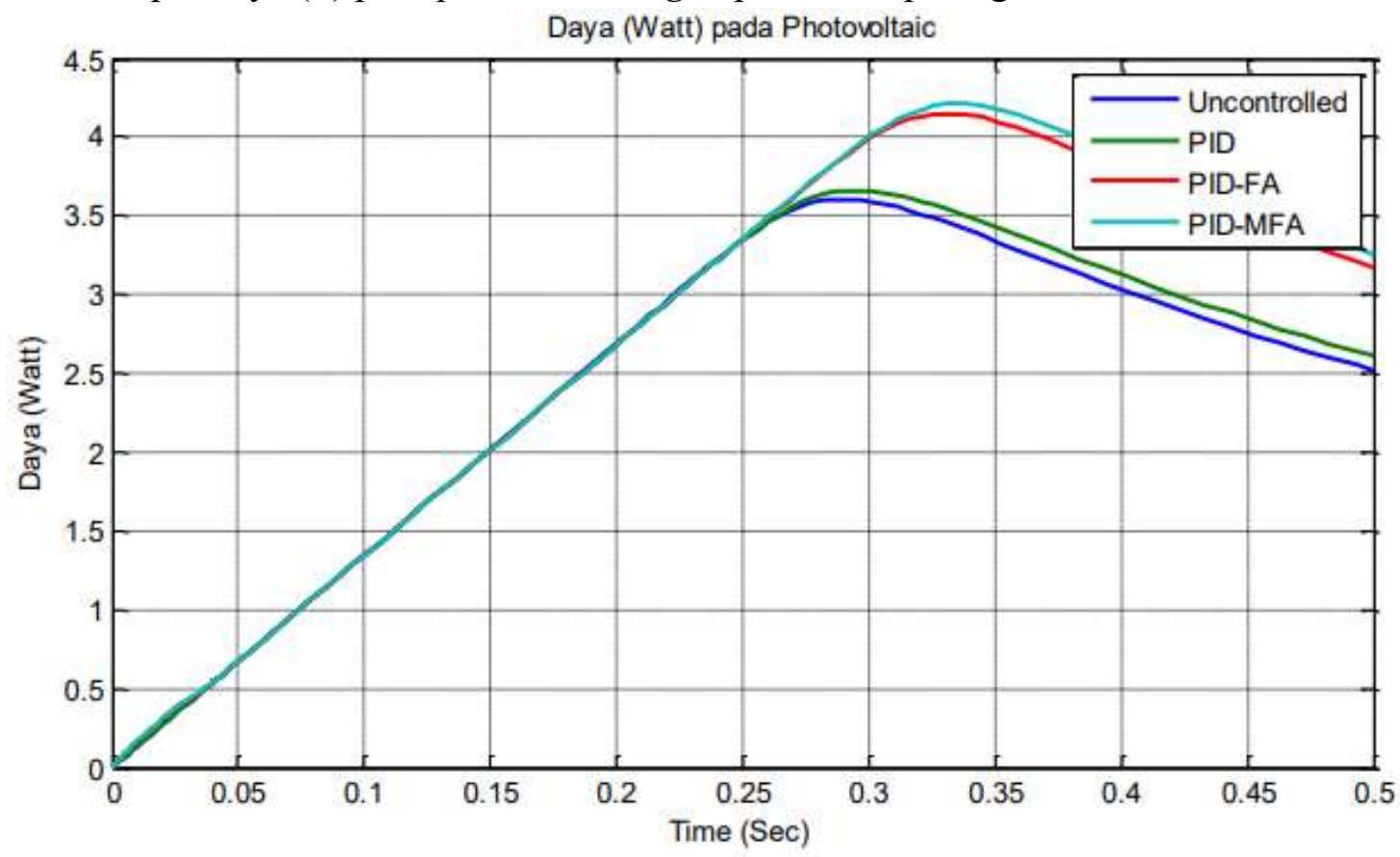

Gambar 6 Ouput Daya Pada Partial Shading Pada PV 


\section{Kesimpulan}

Dari hasil simulasi didapatkan bahwa tegangan terbaik diperoleh dari kontroler PID-MFA yaitu sebesar $1.2755 \mathrm{pu}$, Arus terbaik pada PID-MFA sebesar 4,313; $3.67 ; 2,551 \mathrm{pu}$, dan daya maksimum sebesar 3,253 pu. Dengan demikian dapat disimpulkan bahwa kontroler terbaik pada PID-MFA. Penelitian ini nanti bisa dipakai sebagai acuan dan digunakan kontroler lain agar diperoleh kontroler yang optimal.

\section{Daftar Pustaka}

Suhadak and M. Ali, "Optimasi Steering Control Mobil Listrik Auto-Pilot Menggunakan Metode Firfly Algorithm (FA),” Semnasinotek-2017, vol. 1, no. 1, pp. 61-68, 2017.

M. Ali, Muhlasin, H. Nurohmah, A. Raikhani, H. Sopian, and N. Sutantra, "Combined ANFIS method with FA, PSO, and ICA as Steering Control Optimization on Electric Car," in 2018 Electrical Power, Electronics, Communications, Controls and Informatics Seminar (EECCIS), Oct. 2018, pp. 299-304, doi: 10.1109/EECCIS.2018.8692885.

M. Ali and A. Suhadak, "Optimisasi Steering Control Mobil Listrik Auto-Pilot Menggunakan Metode Firefly Algorithm (FA)," in Semnasinotek 2017, UN PGRI, Kediri, 2017, pp. 61-68.

D. H. Kusuma, M. Ali, and N. Sutantra, "The comparison of optimization for active steering control on vehicle using PID controller based on artificial intelligence techniques," in Proceedings - 2016 International Seminar on Application of Technology for Information and Communication, ISEMANTIC 2016, Mar. 2017, pp. 18-22, doi: 10.1109/ISEMANTIC.2016.7873803.

Kadaryono, Rukslin, M. Ali, Askan, A. Parwanti, and I. Cahyono, "Comparison of LFC Optimization on Micro-hydro using PID, CES, and SMES based Firefly Algorithm," in 2018 5th International Conference on Electrical Engineering, Computer Science and Informatics (EECSI), Oct. 2018, pp. 204-209, doi: 10.1109/EECSI.2018.8752733.

R. Fajardika, M. Ali, M. Muhlasin, and M. Arrohman, "Optimasi Frekuensi Kontrol pada Sistem Hybrid Wind-Diesel Menggunakan PID Kontroler Berbasis ACO dan MFA," J. Rekayasa Mesin, vol. 9, no. 1, pp. 65-68, 2018, doi: 10.21776/ub.jrm.2018.009.01.10.

Budiman, M. Ali, and M. R. Djalal, "Kontrol Motor Sinkron Permanen Magnet Menggunakan Algoritma Firefly," in SEMANTIKOM 2017, Universitas Madura, 2017, pp. 9-16, [Online]. Available: http://semantikom.unira.ac.id/2017/SEMANTIKOM_2017_paper_3.pdf.

M. Ali, "Kontrol Kecepatan Motor DC Menggunakan PID Kontroler Yang Ditunning Dengan Firefly Algorithm," J. Intake, vol. 3, no. 2, pp. 1- 10, 2012, [Online]. Available: http://ejournal.undar.ac.id/index.php/intake/article/view/428. 
M. Ali, A. N. Afandi, A. Parwati, R. Hidayat, and C. Hasyim, "Design Of Water Level Control Systems Using PID and ANFIS Based on Firefly Algorithm," JEEMECS (Journal Electr. Eng. Mechatron. Comput. Sci., vol. 2, no. 1, pp. 61-66, Feb. 2019, doi: 10.26905/jeemecs.v2i1.2804.

Kadaryono, Askan, Rukslin, A. Parwanti, M. Ali, and I. Cahyono, "Comparison of LFC optimization on micro-hydro using PID, CES, and SMES based firefly algorithm," in International Conference on Electrical Engineering, Computer Science and Informatics (EECSI), 2018, vol.2018-Octob, pp. 204-209, doi: 10.1109/EECSI.2018.8752733.

M. Ali, H. Nurohmah, Budiman, J. Suharsono, H. Suyono, and M. A. Muslim, "Optimization on PID and ANFIS Controller on Dual Axis Tracking for Photovoltaic Based on Firefly Algorithm," in ICEEIE 2019 - International Conference on Electrical, Electronics and Information Engineering: Emerging Innovative Technology for Sustainable Future, 2019, pp. 53-57, doi: 10.1109/ICEEIE47180.2019.8981428.

H. Nurohmah, A. Raikhani, and M. Ali, "Rekonfigurasi Jaringan Distribusi Radial Menggunakan Modified Firefly Algorithms (MFA) Pada Penyulang Tanjung Rayon Jombang," JEEE-U (Journal Electr. Electron. Eng., vol. 1, no. 2, p. 13, Nov. 2017, doi: 10.21070/jeeeu.v1i2.1064.

S. L. Tilahun and H. C. Ong, "Modified firefly algorithm,” J. Appl. Math., vol. 2012, 2012, doi: $10.1155 / 2012 / 467631$.

M. Ali and M. Muhlasin, “Auto-Tuning Method for Designing Matlab DC Motor Speed Control With PID (Proportional Integral Derivative)," ADRI Int. J. Sci. Eng. Technol., vol. 1, no. 2, pp. $5-8,2017$.

X. S. Yang, "Firefly Algorithm," Nature-Inspired Metaheuristic Algorithms, pp. 79-90, 2007.

Hendro Dripoyono, Septa Dwi Candra, Dwi Ajiatmo, Budiman, and Machrus Ali, "Penggunaan ACO dan FA Dalam Mengoptimasikan PID Controller Untuk Partial Shading pada Photovoltaic", SinarFe7, vol. 1, no. 1, pp. 35-39, 1. 